\title{
Bazı Makarnalık ve Ekmeklik Buğday Çeşitlerinin Kalite Özelliklerinin Araştırılması
}

\author{
Seydi AYDOĞAN ${ }^{1}$, Mehmet ŞAHIN² ${ }^{2}$, Aysun GÖÇMEN AKÇACIK ${ }^{3}$, Berat DEMİR ${ }^{4}$, Sümeyra HAMZAOĞLU5 \\ Enes YAKISSIR 6 \\ Bahri Dağdaş Uluslararası Tarımsal Araştırma Enstitüsü, Konya \\ 1https://orcid.org/0000-0003-0472-1211, ${ }^{2}$ https://orcid.org/0000-0003-2446-5227, ${ }^{3} \mathrm{https}: / /$ orcid.org/0000-0002-8209-0796 \\ ${ }^{4} \mathrm{https}: / /$ orcid.org/0000-0001-6102-2527, ${ }^{5} \mathrm{https} / / /$ orcid.org/0000-0002-0572-3801, ${ }^{6} \mathrm{https}: / / o r c i d . o r g / 0000-0002-0161-9206$ \\ 凶: seydiaydogan@yahoo.com
}

\section{ÖZET}

Bu araştırma bazı makarnalık buğday ve ekmeklik buğday çeşitlerinin kalite özelliklerinin karşılaştırılması amacıyla yürütülmüştür. Yedi makarnalık ve yedi ekmeklik buğday çeşidinin sulu koşullarda tesadüf blokları deneme desenine göre 2 tekerrürlü olarak kalite ve istatistik analizleri yapılmıştır. Araştırma sonuçlarına göre; ekmeklik buğday çeşitlerinde ortalama değerlerin değişim aralığ 31.10-41.31 g, hektolitre ağırlığı 72.38-78.48 kg, protein oranı \% 14.1616.09, ekmek hacmi 410-570 cm3, farinograf su absorbsiyonu \% 62.5068.20, miksograf gelişme süresi 1.43-2.77 dk., miksograf toplam alanı 358-401 Nm olarak belirlenmiştir. Makarnalık buğday çeşitlerinde ortalama değerlerin değişim aralıkları; bin tane ağırlığı 37.05-49.41 g, hektolitre ağırlığ $74.12-78.92 \mathrm{~kg}$, protein oranı \% 14.46-16.07, ekmek hacmi 390-475 cm3, farinograf su absorbsiyonu \% 67.60-71.10, miksograf gelişme süresi 2.18-3.42 dk., miksograf toplam alanı 334-412 Nm olarak bulunmuştur. Ekmeklik buğday çeşitlerinin reolojik hamur özelliklerinin makarnalık buğday çeşitlerinden daha iyi olduğu belirlenmiştir. Fakat kullanım amacına göre hammadde kalite talebinin değişebileceği göz önünde bulundurularak üretim yapılacak çeşit seçimine dikkat edilmelidir.

\section{Research of Quality Traits of Some Durum Wheat and Bread Wheat Varieties}

\section{ABSTRACT}

This research was carried out to compare the quality traits of some durum wheat and bread wheat varieties. Quality of seven durum and seven bread wheat varieties were analyzed in a randomized block design experiment in irrigated conditions. According to the research results, change range of average values in bread wheat varieties were determined as; $31.10-41.31 \mathrm{~g}$ of thousand kernel weight, $72.38-78.48 \mathrm{~kg}$ test weight, $14.16-16.09 \%$ protein content, $410-570 \mathrm{~cm}^{3}$ bread volume, 62.50-68.20\% farinograph water absorption, 1.43-2.77 min farinograph development time, and 358-401 Nm mixograph total area. Range of change of average values in durum wheat varieties were found as; 37.05-49.41 g thousand kernel weight, 74.12-78.92 kg test weight, 14.46-16.07 \% protein content, 390-475 $\mathrm{cm}^{3}$ bread volume, 67.60$71.10 \%$ farinograph water absorption, 2.18-3.42 min farinograph development time, and 334-412 $\mathrm{Nm}$ mixograph total area. It was determined that rheological dough properties of bread wheat varieties were better than durum wheat varieties. Considering the raw material quality demand may change according to the purpose of use, the selection of variety should be paid attention.

\section{Araştırma Makalesi}

\author{
Makale Tarihçesi \\ Geliş Tarihi : 13.05 .2019 \\ Kabul Tarihi : 11.09 .2019
}

\section{Anahtar Kelimeler}

Makarnalık buğday

Ekmeklik buğday

Kalite

\section{Research Article}

$\begin{array}{ll}\text { Article History } & \\ \text { Received } & : 13.05 .2019 \\ \text { Accepted } & : 11.09 .2019\end{array}$
Keywords
Durum wheat
Bread wheat
Quality

\section{To Cite : Aydoğan S, Şahin M, Gökmen Akçacık A, Demir B, Hamzaoğlu S, Yakışır E 2019. Bazı Makarnalık ve Ekmeklik Buğday Çeşitlerinin Kalite Özelliklerinin Araştırılması. KSÜ Tarım ve Doğa Derg 22(Ek Sayı 2): 264-271. DOI: 10.18016/ksutarimdoga.vi.563954.}

\section{GİRİŞ}

İnsan beslenmesindeki en temel besinlerin (unlu mamuller, makarna, irmik, bisküvi, bulgur) hammaddesi olması sebebiyle buğday diğer tarımsal 
ürünlere göre daha fazla önem taşımaktadır. Ülke nüfusunun kalori ve protein ihtiyacinın karşılanmasında buğday dünyada olduğu gibi ülkemizde de stratejik bir üründür. Değişen tüketim alışkanlıkları ve gelişen teknolojiye bağlı olarak, buğday ürünleri çeşitlenmekte ve tüketicilerin istekleri de değişmektedir. Dünyada ve ülkemizde buğday ekim alanları çeşitli faktörlere bağlı olarak değişmektedir. 2017 yılında dünyada buğday ekim alanı 219 milyon hektar üretim 757.7 milyon ton olmuş, ülkemizde ise ekim alanı 7.7 milyon hektar üretim 20.6 milyon ton olup, makarnalık buğdayın üretimdeki oranı ise 2.76 milyon ton olmuştur (Anonymous, 2017). Kalite ve kullanım amacına göre buğdaylar ekmeklik (Triticum aestivum), bisküvilik (Triticum compactum) ve makarnalık (Triticum durum) olarak üç tür içinde yer almaktadır (Morris, 2004). Makarnalık buğdaylar tetraoploid (AABB; $2 \mathrm{n}=$ $4 \mathrm{x}=28)$ olup kalite özellikleri hekzaploid yapıdaki $(2 \mathrm{n}=6 \mathrm{x}=42$, AABBDD) T. aestivum ve $T$. compactum buğdaylarından farklıdır. Makarnalık buğdaylar makarna, bulgur, kuskus ve irmik ürünlerinin üretiminde kullanılmaktadır. Sissons ve ark. (2014) makarnalık buğdayların dünyanın bazı ülkelerinde ekmek yapımında kullanıldığını fakat ekmeklik buğday ile karşılaştırıldığında düşük hacim ve tekstür özelliği gösterdiğini belirtmişlerdir. Buğday kalitesini belirleyen ana faktörlerden birisi protein miktarı ve yapısıdır. Protein miktarı çevreden etkilenmesine rağmen protein kalitesi kalitsal bir özelliktir. Makarnalık buğdaylarda ekmeklik kalitesinin düşüklüğüne, ekmeklik buğdayların kalitesini önemli şekilde etkileyen D-genomu krozomlarmin yokluğunun neden olduğu bilinmektedir (Sapirstein ve ark., 2007). Ayrıca makarnalık buğdaylarda alfagliadin 42'ye sahip çeşitlerin zayıf glutene, alfa gliadin 45 bandına sahip çeşitlerin ise kuvvetli glutene sahip oldukları ifade edilmiştir (Edwards ve ark., 2007). Makarnalık buğdayların endosperm yapısı çok sert, protein oranları genellikle ekmeklik buğdaylarınkinden daha yüksektir. Buğdayların kullanım alanlarının belirlenmesinde protein miktar ve kalitesi belirleyici faktörlerdir.

Bir buğday genotipinin kalitesinin belirlenmesinde, diğer genotiplerle karşılaştırılmassında, son ürün kalitesinin tahmin edilmesinde; fiziksel, kimyasal özelliklerinin yanında reolojik özelliklerinin de belirlenmesi önemlidir. Farinograf ve miksograf gibi reolojik analiz cihazları ile yapılan analizlerde hamurun yoğurmaya karşı gösterdiği davranışlar, direnç, su absorbsiyonu, gelişme süresi, stabilite, yumuşama değeri gibi özellikler değerlendirilebilmekte, incelenen buğday ununun hangi ürün grubu için uygun olabileceğine karar verilebilmektedir. Bu çalışma ile bazı makarnalık ve ekmeklik buğday çeşitlerinin fiziksel özellikleri (bin tane ağırlığı, hektolitre ağırlığı), protein oranı, bazı reolojik kalite parametreleri, ekmek hacmi ve ağırlığının belirlenmesi ile farklılıkları tespit edilmeye çalışılmıştır.

\section{MATERYAL ve METOT}

$\mathrm{Bu}$ araştırmada 2013-2014 üretim yılında, Konya merkez lokasyonunda sulu koşullarda yetiştirilen 7 makarnalık buğday çeşidi (Altıntaş-95, Ç-1252, Dumlupinar, Eminbey, Meram-2002, Selçuklu-97 ve Yelken-2000) ve 7 ekmeklik buğday çeşidi (Ahmetağa, Ekiz, Göksü-99, Gün-91, Konya-2002, Pehlivan ve Tosunbey) materyal olarak kullanılmıştır. 2013-2014 yetiştirme sezonunda Konya merkez lokasyonuna düşen yağış miktarı $320 \mathrm{~mm}$ olarak belirlenmiş, iki defa sulama yapılarak $140 \mathrm{~mm}$ su verilmiştir. Sulu koşullarda ekimle birlikte her parsele $4 \mathrm{~kg} / \mathrm{da} \mathrm{N}$ ve 9 $\mathrm{kg} / \mathrm{da} \mathrm{P}_{2} \mathrm{O}_{5}$ verilmiştir. Üst gübre olarak $8 \mathrm{~kg} / \mathrm{da} \mathrm{N}$ verilmiştir. Çeşitlerde bin tane ağırlığ reolojik testler (farinograf, miksograf) ve ekmek denemeleri yapılmıştır. Laboratuvar çalışmalarında buğday örnekleri, AACC metot 26-95'e göre (\% 14.5 rutubet olacak şekilde) tavlanarak, Brabender Junior değirmende AACC metot 26-50'ye göre öğütülmüştür (Anonymous, 2000). Protein oranı AOAC 992.23'e göre (Anonymous, 2009) belirlenmiştir. Miksograf analizleri, 35 g'llk miksograf cihazı (National Mfg.Co. Lincoln. NE) ile AACC 54-40A, farinograf analizleri (Farinograf-AT, Brabender Germany) AACC 54-21'e göre (Anonymous, 2000) yapılmıştır. Ekmekler \% 14.5 nem esasına göre $100 \mathrm{~g}$ un tartılarak \% 3 maya ve \% 1.5 tuz katılarak farinograf su absorbsiyon değerine göre hesaplanmış olan su ilavesi ile hamur yoğrulup $30 \mathrm{dk}$., $30 \mathrm{dk}$. ve $55 \mathrm{dk}$.' lık fermantasyon süresi sonucunda $220{ }^{\circ} \mathrm{C}$ ' de 25 dakika firında pişirilerek elde edilmiştir. Ekmek hacmi, içinde sorgum tohumu bulunan ekmek hacmi ölçme cihazı ile yer değiştirme metoduna göre belirlenmiştir. Denemelerden elde edilen sonuçların değerlendirilmesinde, varyans analizi (JMP11) istatistik analiz programma göre yapılmış ve farklılıkları önemli olan özelliklerin ortalama değerleri AÖF (\%5) testine göre gruplandırılmıştır (Anonim, 2014).

\section{BULGULAR ve TARTIŞMA}

Konya merkez lokasyonunda 2013-2014 üretim yılında, sulu koşullarda yürütülen bu araştırmada elde edilen bazı kalite özelliklerine ait varyans analiz sonuçları ve önemli görülen farklılıklar $(p<0.01$, $\mathrm{p}<0.05)$ Çizelge'1 de verilmiştir. İncelenen ekmeklik buğday çeşitlerinde bin tane ağırlığı deneme aralığı 31.10-41.31 g arasında değişmiş, deneme ortalaması $36.29 \mathrm{~g}$ olarak belirlenmiştir. Ekmeklik buğday çeşitlerinde en yüksek bin tane ağırlığı Pehlivan çeşidinden, en düşük değer ise Göksu-99 çeşidinden elde edilmiştir. İncelenen makarnalık buğday çeşitlerinde bin tane ağırlığı deneme aralığ $49.41 \mathrm{~g}$ arasında değişmiş, deneme ortalaması $42.72 \mathrm{~g}$ 
Çizelge 1. Ekmeklik ve Makarnalık Buğday Çeşitlerinde İncelenen Özelliklerin Varyans Analizi

\begin{tabular}{|c|c|c|c|c|c|c|c|}
\hline $\begin{array}{l}\text { Ekmeklik } \text { Varyasyon } \\
\text { Kaynağı }\end{array}$ & $\begin{array}{l}\text { Kareler } \\
\text { Toplamı }\end{array}$ & F Değeri & $\mathbf{P}$ & $\begin{array}{l}\text { Makarnalık Varyasyon } \\
\text { Kaynağı }\end{array}$ & $\begin{array}{l}\text { Kareler } \\
\text { Toplamı } \\
\end{array}$ & F Değeri & $\mathbf{P}$ \\
\hline Bin Tane Ağırlığ & 174.20724 & 2438902 & $<.0001^{* *}$ & Bin Tane Ağırlığ & 286.5920 & $73485.14^{* * *}$ & $<.0001$ \\
\hline Protein Oranı & 8.0078857 & 5547123 & $<.0001^{* *}$ & Protein Oranı & 3.873371 & $2.772513^{* * *}$ & $<.0001$ \\
\hline Hektolitre Ağırlı̆ğ & 56.974470 & 38054.6 & $<.0001^{* *}$ & Hektolitre Ağırlığg & 41.04328 & $118.6792^{* * *}$ & $<.0001$ \\
\hline Ekmek Ağırlığı & 56.908043 & 1327850 & $0.0012^{*}$ & Ekmek Ağırlığı & 812.9174 & $156760.9^{*}$ & 0.0013 \\
\hline Ekmek Hacimi & 39485.714 & 1.50121 & $<.0001^{* *}$ & Ekmek Hacmi & 24285.71 & $9.148513^{* * *}$ & $<.0001$ \\
\hline F. Gelişme Süresi & 43.472443 & 11146.7 & $<.0001^{* *}$ & F.Gelişme Süresi & 9.405385 & $50644.38^{* * *}$ & $<.0001$ \\
\hline F. Su Absorbsiyonu & 56.004043 & 16132.8 & $<.0001^{* *}$ & F. Su Absorbsiyonu & 16.88000 & $3256214^{* * *}$ & $<.0001$ \\
\hline M. Gelişme Süresi & 2.1598857 & 1325655 & $0.0012^{*}$ & M. Gelişme Süresi & 3.476342 & $12167.20^{*}$ & 0.0012 \\
\hline M. Pik Yüksekliği & 210.08788 & 1218405 & $<.0001^{* *}$ & M.Pik Yüksekliği & 358.9977 & $1256492^{* * *}$ & $<.0001$ \\
\hline M.Yumuşama Dere & 171.69674 & 2236555 & $<.0001^{* *}$ & M. Yumuşama Der & 61.25028 & $235652.1^{* *}$ & $<.0001$ \\
\hline M. Pik Genişliği & 69.215527 & 22513.4 & $<.0001^{* *}$ & M. Pik Genişliği & 120.2238 & $27405.45^{*}$ & 0.0015 \\
\hline M. Pik Alanı & 3689.5759 & 5041388 & $<.0001^{* *}$ & M. Pik Alanı & 10337.08 & $2002756^{* * *}$ & $<.0001$ \\
\hline M. Toplam Alan & 2893.7346 & 71343.1 & $<.0001^{* *}$ & M. Toplam Alan & 11655.21 & $70476.74^{* * *}$ & $<.0001$ \\
\hline
\end{tabular}

*,**: Sirasıyla 0.05 ve 0.01 düzeyinde önemli, F: Farinograf, M: Miksograf

olarak belirlenmiştir. Makarnalık buğday çeşitlerinde en yüksek bin tane ağırlığı Eminbey çeşidinden, en düşük bin tane ağırlığı ise Altıntaş-95 çeşidinden elde edilmiş olup, genel olarak değerlendirdiğimizde bin tane ağırlığı bakımından $6.43 \mathrm{~g}$ farkla makarnalık buğdaylarda daha yüksek değer elde edilmiştir. Szumilo ve ark. (2010), yapmış oldukları bir çalışmada makarnalık buğday genotiplerinde bin tane ağırlığının ekmeklik buğdaylara kıyasla daha yüksek olduğunu belirtmişlerdir. Ekmeklik buğdaylarda hektolitre ağırlığ 1 deneme aralığ $\breve{1}_{1}$ 72.38-78.48 kg arasında değişmiş, deneme ortalaması $76.11 \mathrm{~kg}$ olarak belirlenmiştir. Ekmeklik buğday çeşitlerinde en yüksek hektolitre ağırlığ̣ Konya-2002 çeşidinde tespit edilmiştir. Makarnalık buğday çeşitlerinde hektolitre ağırlığ değişmiş, deneme ortalaması $76.55 \mathrm{~kg}$ olarak belirlenmiştir. Makarnalık buğday çeşitlerinde en yüksek hektolitre ağırlığı Yelken-2000, en düşük değer ise Eminbey çeşidinden elde edilmiştir. Ekmeklik ve makarnalık buğdayların ortalama hektolitre ağırlığ arasındaki fark $0.44 \mathrm{~kg}$ olup, makarnalık buğdaylarda yüksek değer tespit edilmiştir. Hektolitre ağırlığı hem genotip hem de çevre şartlarından etkilenen fiziksel bir özelliktir. Makarnalık buğday çeşitlerinde hektolitre ağırlığı ve bin tane ağırlığının yüksek olmasindan danenin fizyolojik tane dolum dönemini iyi değerlendirdiği anlaşlmaktadır. Tane kalitesi, tanenin fiziksel ve bileşimsel özelliklerinin son kullanım amacına uygunluğudur. Tane protein oranı ve bileşimi, son kullanım kalitesini, reolojik özellikleri (hamur kuvveti, gelişme süresi, uzayabilirlik, yumuşama) ve ekmek hacmini etkileyen önemli bir kalite ölçüsüdür ki bunların hepsi ekmek yapım işleminin etkinliğini ve ürün kalitesini belirler (Nuttall ve ark., 2017). Protein oranı makarna ve ekmek kalitesini belirleyen en önemli faktördür (Sissons, 2004). İncelenen ekmeklik buğday çeşitlerinde protein oranı deneme aralığ $\%$ 14.1616.09 arasında değişmiş, deneme ortalaması \% 15.03 olarak belirlenmiştir. Ekmeklik buğday çeşitleri içinde en yüksek protein oranı Tosunbey, en düşük protein oranı ise Ahmetağa çeşidinden elde edilmiştir. İncelenen makarnalık buğday çeşitleri içinde ise protein oranı deneme aralığı \% 14.46-16.07 arasında değişmiş, deneme ortalaması \% 15.45 olarak tespit edilmiştir. Makarnalık buğday çeşitleri içinde en yüksek protein oranı Meram-2002, en düşük protein oranı ise Altıntaş-95 çeşidinden elde edilmiş̧tir. Çalışmada incelenen ekmeklik ve makarnalık buğday çeşitlerinin protein oranı arasındaki fark \% 0.42 olup, makarnalık buğdaylarda yüksek değer tespit edilmiştir (Çizelge 2).

Buğdayın gerek sanayide gerekse ticari amaçla değer kazanmasında ekmeklik özellikleri etkili olmaktadır. İncelenen ekmeklik buğday çeşitlerinde ekmek ağırlığı deneme aralığ̣ 138.61-143.31 g arasında değişmiş, deneme ortalaması $141.13 \mathrm{~g}$ olarak belirlenmiştir. Ekmeklik buğday çeşitlerinde en yüksek ekmek ağırlığ $\breve{g}_{1}$ Konya-2002 çeşidinden, en düşük ekmek ağırlığı ise Ekiz çeşidinden elde edilmiştir. Makarnalık buğday çeşitlerinde ekmek ağırlığ 1 deneme aralığ 126.40-151.00 g arasında değişmiş, deneme ortalaması 142.56 g olarak tespit edilmiştir. Makarnalık buğday çeşitlerinde en yüksek ekmek ağırlığ Dumlupınar çeşidinden, en düşük ekmek ağırlığı ise Altıntaş-95 çeşidinden elde edilmiştir. Ekmeklik ve makarnalık buğdaylar ekmek ağırlığı arasında fark ise $1.43 \mathrm{~g}$ olup makarnalık buğdaylarda yüksek değer elde edilmiştir. Makarnalık buğdaylarda tane yapısının sert olmasına bağlı olarak öğütme sırasında zedelenmiş nişasta oranının yükselmesine neden olduğu, buna bağlı olarak hamurun su absorbsiyon değerlerinde artışa neden olduğu düşünülmektedir. İncelenen ekmeklik buğday çeşitlerinde ekmek hacmi deneme aralığ ${ }^{4}$ 10$570 \mathrm{~cm}^{3}$ arasında değişmiş, deneme ortalaması 482.14 $\mathrm{cm}^{3}$ olarak belirlenmiştir. Ekmeklik buğday çeşitlerinde en yüksek ekmek hacmi Ahmetağa çeşidinden, en düşük ekmek hacmi ise Pehlivan çeşidinden elde edilmiştir. İncelenen makarnalık buğday çeşitlerinde ekmek hacmi deneme aralığı 390- 
$475 \mathrm{~cm}^{3}$ arasında değişmiş, deneme ortalaması 430 $\mathrm{cm}^{3}$ olarak belirlenmiştir. Makarnalık buğday çeşitlerinde en yüksek ekmek hacmi Eminbey, en düşük ekmek hacmi ise Meram-2002 çeşidinden elde edilmiştir. Ekmeklik ve makarnalık buğdaylar ekmek hacmi arasinda fark ise $52.14 \mathrm{~cm}^{3}$ olup ekmeklik buğdaylarda yüksek değer tespit edilmiştir (Çizelge 3). Şahin ve ark. (2013) kuru koşullarda yetiştirilen ekmeklik buğday genotiplerinde ortalama ekmek hacmini $473 \mathrm{~cm}^{3}$, sulu koşullarda yetiştirilen genotiplerde $470 \mathrm{~cm}^{3}$ olduğunu ve ortalamalar arasındaki farkın istatistiki bakımından önemsiz bulunduğunu tespit etmişlerdir. Boyacıoğlu ve D’Appolonia (1994) makarnalık buğdayların öncelikle makarna ürünleri üretmek için kullanılacağını ancak ekmek yapımında da potansiyele sahip olduğunu belirtmişlerdir. Makarnalık buğdaydan yapılan ekmeğin, ekmeklik buğdaydan yapılana göre daha küçük hacimli olduğu, buna rağmen durum buğdayı ekmeğinin daha sarı renkli, kendine özgü tat ile kokuda olup raf ömrünün daha uzun olduğu belirtilmektedir (Pehlivan ve İkincikarakaya, 2017). İyi bir ekmek yapım unu, hamur oluşumu sırasında geniş bir viskoelastik matris üretebilen güçlü gluteni gerekli kılar (Sissons, 2008). Abecassis ve ark. (2012) iyi bir ekmek yapmak için protein oranı, su absorbsiyonu, hamur kuvveti ve esnekliği özelliklerinin önemli olduğunu, makarnalık buğdaylarda ekmek hacminin genel olarak ekmeklik buğdayınkinden daha düşük olduğunu, makarnalık buğdayda ekmeğin hacim kazanmasında önemli olan hamur elastikiyetinin bir eksiklik olduğunu belirtmişlerdir.

Çizelge 2. Ekmeklik ve Makarnalık Buğday Çeşitlerinin Bin Tane Ağırlığı, Hektolitre Ağırlığı ve Protein Oranı Ortalama Değerleri

\begin{tabular}{|c|c|c|c|c|c|c|c|c|c|c|c|}
\hline \multicolumn{4}{|c|}{ Bin Tane Ağırlığı (g) } & \multicolumn{4}{|c|}{ Hektolitre Ağırlığı（kg） } & \multicolumn{4}{|c|}{ Protein (\%) } \\
\hline Ekmeklik & & Makarnalıl & & Ekmeklik & & Makarnalıl & & Ekmeklik & & Makarnalıl & \\
\hline Ahmetağa & 32.31 & Altıntaş-95 & 37.05 & Ahmetağa & 75.44 & Altıntaş-95 & 78.05 & Ahmetağa & 14.16 & Altıntaş-95 & 14.46 \\
\hline Ekiz & 36.61 & Ç- 1252 & 41.61 & Ekiz & 76.31 & Ç- 1252 & 75.44 & Ekiz & 14.75 & C- 1252 & 15.67 \\
\hline Göksu-99 & 31.10 & Dumlupinar & 48.41 & Göksu-99 & 72.38 & Dumlupinar & 77.18 & Göksu-99 & 16.02 & Dumlupinar & 14.94 \\
\hline Gün-91 & 39.11 & Eminbey & 49.41 & Gün-91 & 77.61 & Eminbey & 74.12 & Gün-91 & 15.49 & Eminbey & 15.76 \\
\hline Konya-2002 & 39.11 & Meram-2002 & 44.71 & Konya-2002 & 78.48 & Meram-2002 & 77.61 & Konya-2002 & 14.55 & Meram-2002 & 16.07 \\
\hline Pehlivan & 41.31 & Selcuklu-97 & 39.51 & Pehlivan & 74.55 & Selcuklu-97 & 74.55 & Pehlivan & 14.24 & Selcuklu-97 & 15.86 \\
\hline Tosunbey & 34.51 & Yelken-2000 & 38.41 & Tosunbey & 78.05 & Yelken-2000 & 78.92 & Tosunbey & 16.09 & Yelken-2000 & 15.45 \\
\hline Ortalama & 36.29 & & 42.72 & & 76.11 & & 76.55 & & 15.03 & & 15.45 \\
\hline $\mathrm{AÖO}_{(0.05)}$ & 3.14 & & 3.58 & & 1.45 & & 1.65 & & 1.03 & & 0.78 \\
\hline $\mathrm{DK}_{(\%)}$ & 6.31 & & 5.75 & & 5.48 & & 4.99 & & 4.17 & & 3.87 \\
\hline
\end{tabular}

Çizelge 3. Ekmeklik ve Makarnalık Buğday Çeşitlerinin Ekmek Ağırlığı ve Ekmek Hacmi Ortalama Değerleri

\begin{tabular}{llllllll}
\hline \multicolumn{2}{l}{ Ekmek Ağırlı̆̆ $(\mathbf{g})$} & \multicolumn{5}{c}{ Ekmek Hacmi $\left(\mathbf{c m}^{3}\right)$} \\
\hline Ekmeklik & & Makarnalık & & Ekmeklik & Makarnalık & \\
\hline Ahmetağa & 142.21 & Altıntaş-95 & 126.40 & Ahmetağa & 570 & Altıntaş-95 & 405 \\
Ekiz & 138.61 & Ç-1252 & 137.90 & Ekiz & 485 & Ç-1252 & 465 \\
Göksu-99 & 139.11 & Dumlupınar & 151.00 & Göksu-99 & 425 & Dumlupınar & 465 \\
Gün-91 & 142.81 & Eminbey & 145.20 & Gün-91 & 515 & Eminbey & 475 \\
Konya-2002 & 143.31 & Meram-2002 & 143.40 & Konya-2002 & 520 & Meram-2002 & 390 \\
Pehlivan & 138.81 & Selcuklu-97 & 145.50 & Pehlivan & 410 & Selcuklu-97 & 410 \\
Tosunbey & 143.11 & Yelken-2000 & 148.50 & Tosunbey & 450 & Yelken-2000 & 400 \\
\hline Ortalama & 141.13 & & 142.56 & & 482.14 & & 430 \\
\hline AÖF(0.05) & 1.45 & & 2.20 & & 22.12 & & 14.47 \\
DK(\%) & 6.47 & & 5.75 & & 4.92 & & 5.78 \\
\hline
\end{tabular}

Farinograf, parametreleri hamurun yoğrulma ve ekmeklik özellikleri hakkında bilgi sağlamaktadır. Farinograf özellikleri gluten proteinlerinin miktar ve kalitesi ile ilgilidir. İncelenen ekmeklik buğday çeşitlerinde farinograf gelişme süresi deneme aralığ 3.59-8.52 dk. arasında değişmiş, deneme ortalaması $6.62 \mathrm{dk}$. olarak belirlenmiştir. Ekmeklik buğday çeşitlerinde en yüksek farinograf gelişme süresi Ahmetağa, en düşük farinograf gelişme süresi ise Ekiz çeşidinden elde edilmiştir. Makarnalık buğday çeşitlerinde farinograf gelişme süresi deneme aralığ 2.05-4.34 dk. arasında değişmiş, deneme ortalaması $2.90 \mathrm{dk}$. olarak belirlenmiştir. Makarnalık buğday çeşitlerinde en yüksek farinograf gelişme süresi Eminbey, en düşük farinograf gelişme süresi ise Meram-2002 çeşidinden elde edilmiştir. Ekmeklik ve makarnalık buğday çeşitlerinde farinograf gelişme süresi arasındaki fark $3.72 \mathrm{dk}$. olup ekmeklik buğdaylarda yüksek değer elde edilmiştir. Ekmeklik buğdaylarda farinograf gelişme süresinin yüksek olmasının nedeninin gluten proteinlerinin miktarı ve elastikiyetinin makarnalık buğdaylara göre fazla olmasından kaynaklandiğı düşünülmektedir. Ekmeklik buğdaylarda su absorbsiyon değeri deneme aralığ $\breve{1}_{1}$ 62.50-68.20 arasında değişmiş, deneme ortalaması \% 66.32 olarak belirlenmiştir. İncelenen 
ekmeklik buğday çeşitlerinde en yüksek farinograf su absorbsiyon değeri Pehlivan çeşidinde, en düşük farinograf su absorbsiyon değeri ise Göksu-99 çeşidinde tespit edilmiştir. İncelenen makarnalık buğday çeşitlerinde farinograf su absorbsiyon değeri deneme aralığı \% 67.60-71.10 arasında değişmiş, deneme ortalaması \% 70.10 olarak belirlenmiştir. Makarnalık buğday çeşitlerinde en yüksek farinograf su absorbsiyon değeri Dumlupınar, en düşük farinograf su absorbsiyon değeri Altıntaş-95 çeşidinde elde edilmiştir. Ekmeklik ve makarnalık buğday çeşitlerinin farinograf $\mathrm{su}$ absorbsiyon değerleri arasındaki fark \% 3.78 olup makarnalık buğdaylarda yüksek değer tespit edilmiştir (Çizelge 4). Makarnalık buğdaylarda su absorbsiyonunun yüksek olması zedelenmiş nişasta oranının yüksek olmasından kaynaklanmaktadır. Benzer bir çalışmada Dexter ve ark. (1994) zedelenmiş nişasta miktarının, farinograf su absorbsiyonunu, gelişme süresini ve kararlılığını etkileyen baskın faktör olduğunu belirtmişlerdir. Szumilo ve ark. (2010) makarnalık buğdaylarda su absorsiyonunun ekmeklik buğdaylara göre daha yüksek olduğunu belirlemişler, su absorbsiyonunun yüksek olmasının iyi bir teknolojik kalitenin göstergesi olduğunu bildirmişlerdir.

Çizelge 4. Ekmeklik ve Makarnalık Buğday Çeşitlerinin Farinograf Gelişme Süresi ve Farinograf Su Absorbsiyonu Ortalama Değerleri

\begin{tabular}{|c|c|c|c|c|c|c|c|}
\hline \multicolumn{4}{|c|}{ Farinograf Gelişme Süresi (dk.) } & \multicolumn{4}{|c|}{ Farinograf Su Absorbsiyonu (\%) } \\
\hline Ekmeklik & & Makarnalık & & Ekmeklik & & Makarnalık & \\
\hline Ahmetağa & 8.52 & Altıntaş-95 & 3.55 & Ahmetağa & 65.10 & Altıntaş-95 & 67.60 \\
\hline Ekiz & 3.59 & C- 1252 & 2.50 & Ekiz & 66.30 & C- 1252 & 70.40 \\
\hline Göksu-99 & 8.04 & Dumlupinar & 2.11 & Göksu-99 & 62.50 & Dumlupınar & 71.10 \\
\hline Gün-91 & 7.37 & Eminbey & 4.34 & Gün-91 & 67.80 & Eminbey & 70.20 \\
\hline Konya-2002 & 4.29 & Meram-2002 & 2.05 & Konya-2002 & 67.70 & Meram-2002 & 69.80 \\
\hline Pehlivan & 7.05 & Selcuklu-97 & 2.28 & Pehlivan & 68.20 & Selcuklu-97 & 70.90 \\
\hline Tosunbey & 7.49 & Yelken-2000 & 3.46 & Tosunbey & 67.10 & Yelken-2000 & 70.70 \\
\hline Ortalama & 6.62 & & 2.90 & & 66.32 & & 70.10 \\
\hline $\mathrm{AÖF}_{(0.05)}$ & 2.41 & & 1.56 & & 1.02 & & 0.98 \\
\hline $\mathrm{DK}_{(\%)}$ & 4.75 & & 3.97 & & 5.96 & & 5.21 \\
\hline
\end{tabular}

Miksograf analizinde hamur yoğurma sirasında belirli reolojik ölçümler yapılır ve elde edilen ölçümler son kullanım kalitesinin iyi bir göstergesidir (Bordes ve ark., 2008). Ekmeklik buğdaylarda miksograf gelişme süresi deneme aralığı 1.43-2.77 dk. arasında değişmiş, deneme ortalaması $2.10 \mathrm{dk}$. olarak belirlenmiştir. İncelenen ekmeklik buğday çeşitlerinde en yüksek miksograf gelişme süresi Tosunbey çeşidinde belirlenmiştir. Aydoğan ve ark. (2010) 2009-2010 yıllarında sulu koşullarda 16 ekmeklik buğday çeşidi ile yaptıkları bir çalışmada denemede yer alan çeşitlerin miksograf gelişme süresinin 1.80-4.98 dk., arasında değiştiğini çeşitlerin ortalama gelişme süresinin $2.94 \mathrm{dk}$. olduğunu, en yüksek gelişme süresinin $4.98 \mathrm{dk}$. ile Tosunbey çeşidinden elde edildiğini tespit etmişlerdir. Li ve ark. (2013) hamur reolojik özeliklerindeki varyasyonun genotip ve çevreden etkilendiğini, reolojik özellikler üzerine genotip etkisinin yüksek olduğu bildirmişlerdir. İncelenen makarnalık buğday çeşitlerinde miksograf gelişme süresi deneme aralığ $2.18-3.42 \mathrm{dk}$. arasında değişmiş, deneme ortalaması $2.63 \mathrm{dk}$. olarak belirlenmiştir. Makarnalık buğday çeşitlerinde en yüksek miksograf gelişme süresi Eminbey çeşidinde tespit edilmiştir. Incelenen ekmeklik ve makarnalık buğday çeşitlerinin miksograf gelişme süresi arasındaki fark $0.53 \mathrm{dk}$. olup makarnalık buğdaylarda yüksek değer elde edilmiştir. Aydoğan ve ark. (2014) makarnalık buğdayda miksograf parametrelerini inceledikleri bir çalışmada gelişme süresinin sulu koşullarda 1.69-3.45 dk., kuru koşullarda ise 1.37-2.37 dk. arasında değiştiğini belirlemişlerdir. Ekmeklik buğdaylarda miksograf pik yüksekliği deneme aralığı \% 69.15-79.34 arasında değişmiş, deneme ortalaması \% 74.25 olarak belirlenmiştir. Ekmeklik buğday çeşitlerinde en yüksek pik yüksekliği Konya-2002 çeşidinde, en düşük değer ise Pehlivan çeşidinde belirlenmiştir. Aydoğan ve ark. (2010), 2009-2010 yıllarında yaptıkları bir çalışma sonucunda 16 ekmeklik buğday çeşidinin sulu koşullarda miksograf pik yüksekliği deneme ortalamasının $\% 60.51$ olduğunu, en yüksek pik yüksekliğinin \% 70.99 ile Demir-2000 çeşidinden elde edildiğini tespit etmişlerdir. Makarnalık buğdaylarda miksograf pik yüksekliği deneme aralığı \% 63.73-79.13 arasında değişmiş, deneme ortalaması \% 69.99 olarak belirlenmiştir. Makarnalık buğday çeşitlerinde en yüksek pik yüksekliği Eminbey çeşidinden, en düşük değer ise Ç-1252 çeşidinden elde edilmiştir. İncelenen ekmeklik ve makarnalık buğday çeşitlerinin miksograf pik yüksekliği arasındaki fark \% 4.26 olup ekmeklik buğdaylarda yüksek değer tespit edilmiştir (Çizelge 5).

Çizelge 5. Ekmeklik ve Makarnalık Buğday Çeşitlerinin Miksograf Gelişme Süresi ve Miksograf Pik Yüksekliği Ortalama Değerleri 


\begin{tabular}{|c|c|c|c|c|c|c|c|}
\hline \multicolumn{4}{|c|}{ Miksograf Gelişme Süresi (dk.) } & \multicolumn{4}{|c|}{ Miksograf Pik Yüksekliği (\%) } \\
\hline Ekmeklik & & Makarnalık & & Ekmeklik & & Makarnalık & \\
\hline Ahmetağa & 2.40 & Altıntaş-95 & 2.18 & Ahmetağa & 77.46 & Altıntaş-95 & 66.61 \\
\hline Ekiz & 2.02 & C- 1252 & 2.48 & Ekiz & 78.61 & C- 1252 & 63.73 \\
\hline Göksu-99 & 1.84 & Dumlupinar & 2.45 & Göksu-99 & 71.78 & Dumlupinar & 71.87 \\
\hline Gün-91 & 1.43 & Eminbey & 3.42 & Gün-91 & 73.23 & Eminbey & 79.13 \\
\hline Konya-2002 & 2.23 & Meram-2002 & 2.71 & Konya-2002 & 79.34 & Meram-2002 & 68.20 \\
\hline Pehlivan & 2.06 & Selcuklu-97 & 2.21 & Pehlivan & 69.15 & Selcuklu-97 & 65.81 \\
\hline Tosunbey & 2.77 & Yelken-2000 & 3.01 & Tosunbey & 70.17 & Yelken-2000 & 74.60 \\
\hline Ortalama & 2.10 & & 2.63 & & 74.25 & & 69.99 \\
\hline $\mathrm{AÖF}(0.05)$ & 0.45 & & 0.33 & & 2.47 & & 3.10 \\
\hline $\mathrm{DK}_{(\%)}$ & 5.78 & & 5.14 & & 4.87 & & 5.14 \\
\hline
\end{tabular}

Ekmeklik buğdaylarda pik yüksekliğinin yüksek olması gluten direncinin yüksek olmasından kaynaklanmaktadır. Mao ve ark. (2013) genel olarak, güçlü hamurların gelişme sürelerinin uzun, pik değerlerinin yüksek olduğunu belirtmişlerdir. Incelenen ekmeklik buğday çeşitlerinde miksograf yumuşama derecesi deneme aralığı 7.60-13.14\%/dk. arasında değişmiş, deneme ortalaması $11.18 \%$ /dk. olarak belirlenmiştir. En yüksek yumuşama derecesi Pehlivan çeşidinde, en düşük yumuşama derecesi ise Tosunbey çeşidinden elde edilmiştir. Hamurun gelişme süresinin yüksek olmasının yanında yumuşama derecesinin de düşük olması istenmektedir. Aydoğan ve ark. (2010) yumuşama derecesinin düşük olmasının gluten ağlarının kuvvetli olduğunu ve hamurun paletlere kuvvetli bir direnç göstereceğini ifade etmekte olduğunu, 16 ekmeklik buğday çeşidi ile sulu koşullarda yaptıkları bir çalışmada, en düşük yumuşama derecesinin Tosunbey çeşidinden elde edildiğini belirtmişlerdir. İncelenen makarnalık buğday çeşitlerinde miksograf yumuşama derecesi deneme aralığ $11.24-16.00 \% / d k$. arasında değişmiş, deneme ortalaması $13.93 \% / d k$. olarak belirlenmiştir. En yüksek yumuşama derecesi Meram2002, en düşük yumuşama derecesi ise Eminbey çeşidinden elde edilmiştir. İncelenen ekmeklik ve makarnalık buğday çeşitlerinde miksograf yumuşama derecesi arasında fark $2.75 \% / d k$. olup makarnalık buğdaylarda yüksek değer elde edilmiştir. İncelenen ekmeklik buğday çeşitlerinde miksograf pik genişliği deneme aralığı \% 5.17-9.93 arasında değişmiş, deneme ortalaması \% 7.66 olarak belirlenmiştir. Ekmeklik buğday çeşitlerinde en yüksek pik genişliği Ekiz, en düşük pik genişliği ise Pehlivan çeşidinden elde edilmiştir. Pik genişliği hamurun mikser pimlerine gösterdiği direnç olup yüksek olması ekmeklik buğday için istenen bir durumdur. Incelenen makarnalık buğday çeşitlerinde miksograf pik genişliği deneme aralığı \% 3.88-7.52 arasında değişmiş, deneme ortalaması \% 5.64 olarak belirlenmiştir. Makarnalık buğday çeşitlerinde en yüksek pik genişliği Eminbey, en düşük pik genişliği ise Selçuklu-97 çeşidinden elde edilmiştir. Incelenen ekmeklik ve makarnalık buğday çeşitlerinde miksograf pik genişliği arasındaki fark \% 2.02 olup ekmeklik buğdaylarda yüksek değer tespit edilmiştir (Çizelge 6).

Ekmeklik buğdaylarda pik genişliğinin yüksek olmasının gluten direncinin yüksek olup analiz sonuna kadar glutenin mukametini korumakta olmasından kaynaklı olduğu düşünülmektedir. Miksograf pik alanının yüksek olması yoğrulan hamurun gluten yapısının kuvvetli olduğunu, yoğrulma sirasında hamurun paletlere vermiş olduğu direncin fazla olduğunu göstermektedir. Buna bağlı olarak pik alanının geniş olmasına ve gelişme süresinin de uzun olmasına neden olmaktadır. Ekmeklik buğdaylarda miksograf pik alanı deneme aralığ 1 77-123 Nm arasında değişmiş, deneme ortalaması $98 \mathrm{Nm}$ olarak belirlenmiştir. Incelenen ekmeklik buğdaylarda en yüksek pik alanı Tosunbey, en düşük pik alanı ise Gün-91 ve Pehlivan çeşitlerinden elde edilmiştir. Makarnalık buğday çeşitlerinde pik alanı deneme aralığı 71-111 Nm arasında değişmiş, deneme ortalaması $90 \mathrm{Nm}$ olarak tespit edilmiştir. Makarnalık buğday çeşitlerinde en yüksek pik alanı Eminbey çeşidinden, en düşük pik alanı ise Selçuklu-97 çeşidinden elde edilmiştir. İncelenen ekmeklik ve makarnalık buğday çeşitleri pik alanı arasındaki fark $8 \mathrm{Nm}$ olup ekmeklik buğdaylarda yüksek değer elde edilmiştir. Miksograf toplam alan değerinin yüksek olması iyi bir hamur özelliğinin göstergesi olup gelişme süresinin ve pik yüksekliğinin yüksek olmasına bağlıdır. Ekmeklik buğdaylarda miksograf toplam alanı deneme aralığ ${ }_{1}$ 358-401 Nm arasında değişmiş, deneme ortalaması $375 \mathrm{Nm}$ olarak belirlenmiştir. Ekmeklik buğday çeşitlerinde en yüksek miksograf toplam alan Ekiz çeşidinden, en düşük miksograf toplam alan ise Pehlivan çeşidinden elde edilmiştir. Makarnalık buğday çeşitlerinde miksograf toplam alanı deneme aralığ 1 334-412 Nm arasında değişmiş, deneme ortalaması $365 \mathrm{Nm}$ olarak belirlenmiştir. Makarnalık buğday çeşitlerinde en yüksek miksograf toplam alan Eminbey, en düşük değer ise Ç-1252 çeşidinden elde edilmiştir. İncelenen ekmeklik ve makarnalık buğday çeşitlerinde miksograf toplam alanı arasındaki fark $10 \mathrm{Nm}$ olup ekmeklik buğdaylarda yüksek değer tespit edilmiştir (Çizelge 7). Ekmeklik buğdaylarda miksograf toplam alanın yüksek olmasının gluten direncinin yüksek olmasından kaynaklandığ̀ düşünülmektedir. 
Karababa ve Ercan (1995) yapmış oldukları bir çalışma sonucunda kuvvetli gluten özelliklerine sahip makarnalık buğdayların, kaliteli ekmeklik buğdaylara benzer miksograf değerleri belirlemişlerdir.

Çizelge 6. Ekmeklik ve Makarnalık Buğday Çeşitlerinin Miksograf Yumuşama Derecesi ve Miksograf Pik Genişliği Ortalama Değerleri

\begin{tabular}{|c|c|c|c|c|c|c|c|}
\hline \multicolumn{4}{|c|}{ Miksograf Yumuşama Derecesi (\%/dk.) } & \multicolumn{4}{|c|}{ Miksograf Pik Genişliği (\%) } \\
\hline Ekmeklik & & Makarnalık & & Ekmeklik & & Makarnalık & \\
\hline Ahmetağa & 12.89 & Altıntaş-95 & 14.52 & Ahmetağa & 7.95 & Altıntaş-95 & 5.24 \\
\hline Ekiz & 11.84 & Ç- 1252 & 12.09 & Ekiz & 9.93 & Ç- 1252 & 4.64 \\
\hline Göksu-99 & 10.45 & Dumlupinar & 15.61 & Göksu-99 & 5.50 & Dumlupınar & 5.71 \\
\hline Gün-91 & 11.14 & Eminbey & 11.24 & Gün-91 & 6.84 & Eminbey & 7.52 \\
\hline Konya-2002 & 11.25 & Meram-2002 & 16.00 & Konya-2002 & 9.01 & Meram-2002 & 5.39 \\
\hline Pehlivan & 13.14 & Selcuklu-97 & 15.00 & Pehlivan & 5.17 & Selcuklu-97 & 3.88 \\
\hline Tosunbey & 7.60 & Yelken-2000 & 13.08 & Tosunbey & 9.46 & Yelken-2000 & 7.17 \\
\hline Ortalama & 11.18 & & 13.93 & & 7.66 & & 5.64 \\
\hline $\mathrm{AÖF}(0.05)$ & 1.14 & & 1.54 & & 2.47 & & 1.87 \\
\hline $\mathrm{DK}_{(\%)}$ & 3.15 & & 4.85 & & 4.47 & & 3.98 \\
\hline
\end{tabular}

Çizelge 7. Ekmeklik ve Makarnalık Buğday Çeşitlerinin Miksograf Pik Alanı ve Miksograf Toplam Alan Ortalama Değerleri

\begin{tabular}{llllllll}
\hline \multicolumn{2}{l}{ Miksograf Pik Alan (Nm) } & & \multicolumn{5}{c}{ Miksograf Toplam Alan (Nm) } \\
\hline Ekmeklik & \multicolumn{3}{l}{ Makarnalık } & Ekmeklik & Makarnalık \\
\hline Ahmetağa & 106 & Altıntaş-95 & 83 & Ahmetağa & 380 & Altıntaş-95 & 356 \\
Ekiz & 112 & Ç-1252 & 80 & Ekiz & 401 & Ç-1252 & 334 \\
Göksu-99 & 84 & Dumlupınar & 109 & Göksu-99 & 361 & Dumlupınar & 393 \\
Gün-91 & 77 & Eminbey & 111 & Gün-91 & 365 & Eminbey & 412 \\
Konya-2002 & 110 & Meram-2002 & 101 & Konya-2002 & 387 & Meram-2002 & 336 \\
Pehlivan & 77 & Selcuklu-97 & 71 & Pehlivan & 358 & Selçuklu-97 & 340 \\
Tosunbey & 123 & Yelken-2000 & 80 & Tosunbey & 375 & Yelken-2000 & 385 \\
\hline Ortalama & 98 & & 90 & & 375 & & 365 \\
\hline AÖF(0.05) & 6.21 & & 5.54 & & 4.89 & & 8.15 \\
DK(\%) & 5.14 & & 4.98 & & 3.78 & & 4.12 \\
\hline
\end{tabular}

\section{SONUÇ}

Konya lokasyonunda sulu koşullarda bazı makarnalık ve ekmeklik buğday çeşitlerinin fiziksel ve kimyasal özelliklerinin, hamur reolojisinin, ekmek denemelerinin incelenmesi, ekmeklik ve makarnalık buğday çeşitlerinin karşlaştırılması, farklılık ve benzerliklerine farkındalık oluşturulması amacıyla yürütülen bu çalışmada; İncelenen makarnalık ve ekmeklik buğday çeşitleri arasındaki kalite özellikleri farklılıklarının istatistiki olarak önemli olduğu belirlenmiştir. Çalışmanın yapıldığı yılda incelenen makarnalık buğday çeşitleri bin tane ağırlığı, hektolitre ağırlığı, protein oranı, ekmek ağgrlığı, farinograf su absorbsiyonu, miksograf gelişme süresi özellikleri bakımından ekmeklik buğday çeşitlerine göre yüksek değerler vermişlerdir. Ekmek hacmi, farinograf gelişme süresi, miksograf pik yüksekliği, miksograf pik genişliği, miksograf pik alanı ve miksograf toplam alan bakımından ise ekmeklik buğday çeşitlerinin makarnalık buğday çeşitlerine göre yüksek değer verdiği tespit edilmiştir. Miksograf hamur özellikleri bakımından makarnalık buğday çeşitlerinde Eminbey, ekmeklik buğday çeşitlerinde Ekiz, Konya-2002 ve Tosunbey çeşitlerinin, ekmek hacmi ve ağırlığı bakımından Ahmetağa ve Konya2002 çeşitlerinin yüksek değerler verdiği belirlenmiştir. Makarnalık buğday çeşitleri esas olarak makarna üretimi için uygun olup kimyasal özellikleri, hamur reolojisi ve ekmek özellikleri bakımından ekmeklik buğdaylara benzer özelliklerde göstermekte olup gelişen teknolojiye ve üretimdeki çeşitlenmeye bağlı olarak istenen kalite özelliklerine sahip genotiplerin çeşitli alanlarda kullanılabileceği düşünülmektedir.

\section{KAYNAKLAR}

Abecassis J, Cuq B, Boggini G, Namoune H 2012. Other Traditional Durum-derived Products. In 'Durum Wheat Chemistry and Technology'. (AACC International: St. Paul, MN), 2nd edn pp. 177-199.

Anonymous 2000. Approved methods of the American association of cereal chemists. Amer Assn of Cereal Chemists.

Anonymous 2009. Approvedmethodologies. www.leco. com/Resources/Approved-Methods.

Anonymous 2017. Toprak Mahsulleri Ofisi Genel Müdürlüğü 2017 Yılı Hububat Sektör Raporu. http://www.tmo.gov.tr. 
Anonymous 2014. JMP11, Jsl Syntax Reference. Sas Institute, ISBN: 978: 560-563.

Aydoğan S, Göçmen Akçacık A, Şahin M, Kaya Y, Taner S, Demir B, Önmez H 2010. Ekmeklik Buğday Çeşitlerinin Dane Verimi, Bazı Kimyasal ve Reolojik Özellikleri Üzerine Bir Araştırma. Bitkisel Araştırma Dergisi, 1: 1-7.

Aydoğan S, Şahin M, Göçmen Akçacık A, Hamzaoğlu S, Yakışır E 2014. Makarnalık Buğday Çeşitlerinin Sulu ve Kuru Koşullarda Bazı Kalite Özellikleri ve Miksograf Parametrelerinin Değerlendirilmesi. Uluslararası Mezopotamya Tarım Kongresi, 22-25 Eylül, Diyarbakır.

Bordes J, Branlard G, Oury FX, Charmet G, Balfourier F 2008. Agronomic Characteristics, Grain Quality and Flour Rheology of 372 Bread Wheats in a Worldwide Core Collection. Journal of Cereal Science, 48(3): 569-579.

Boyacıŏ̆lu MH, D’Appolonia BL 1994. Durum Wheat and Bread Products. Cereal Foods World, 39(3): 168-174.

Dexter JE, Preston KR, Martin DG, Gander EJ 1994. The Effects of Protein Content and Starch Damage on the Physical Dough Properties and Breadmaking Quality of Canadian Durum Wheat. Journal of Cereal Science, 20: 139-151

Edwards NM, Gianibelli MC, McCaig TN, Clarke JM, Ames NP, Larroque OR, Dexter JE 2007. Relationships Between Dough Strength, Polymeric Protein Quantity and Composition for Diverse Durum Wheat Genotypes. Journal of Cereal Science, 45(2): 140-149.

Karababa E, Ercan R 1995. Makarnalık Buğdayların Ekmeklik Potansiyeli ve Kalitesi. Gida Dergisi, 20(3): 153-159.

Li Y, Wu Y, Pena RJ 2013. The Influence of Drought and Heat Stress on The Expression ff End-Use Quality Parameters ff Common Wheat. Journal of Cereal Science, 57: 73-78.

Mao X, Li Y, Zhao S, Zhang J, Lei Q, Meng D, Ma F, $\mathrm{Hu}$ W, Chen M, Chang J, Wang Y, Yang G, He G 2013. The Interactive Effects of Transgenically Overexpressed 1Ax1 With Various HMW-GS
Combinations on Dough Quality By Introgression of Exogenous Subunits into An Elite Chinese Wheat Variety. Plos One, 8(10): e78451.

Morris SR 2004. Grain: Quality attributes. In Wrigley, C. et al. (Eds.), Encyclopedia of Grain Science, (238254). Elsevier Ltd., Amsterdam.

Nuttall JG, O'Leary GJ, Panozzo JF, Walker CK, Barlow KM, Fitzgerald GJ 2017. Models of Grain Quality in Wheat.(A review). Field Crops Research, 202: $136-145$.

Pehlivan A, İkincikarakaya Ü 2017. Makarnalık Buğdayda Kalite Islahı Çalışmaları. Tarla Bitkileri Merkez Araştırma Enstitüsü Dergisi, 26(1): 127151.

Sapirstein HD, David KR, Preston J, Dexter E 2007. Durum Wheat Breadmaking Quality: Effects of Gluten Strength, Protein Composition, Semolina Particle Size And Fermentation Time. Journal of Cereal Science, 45(2): 150-161.

Sissons M 2004. Pasta Encyclopedia of Grain Science. Elsevier Ltd., Amsterdam, 410-418.

Sissons M 2008. Role of Durum Wheat Composition on the Quality of Pasta and Bread. Food, Global Science Books, 2(2): 75-90

Sissons M, Pleming D, Margiotta B, Grazia D'Egidio M, Lafiandra D 2014. Effect of The İntroduction of D-Genome Related Gluten Proteins on Durum Wheat Pasta and Bread Making Quality. Crop and Pasture Science, 65(1): 27-37. DOI: 10.1071/CPI13305

Szumilo G, Rachon L, Stankowski S 2010. The Evaluation of Grain and Flour Quality of Spring Durum Wheat (Triticum durum Desf.). Polish Journal of Agronomy, 78-82.

Şahin M, Aydoğan S, Göçmen Akçacık A, Demir B, Önmez H, Taner S, Yakışır E 2013. Orta Anadolu Bölgesinde Ekimi Yapılan Bazı Ekmeklik Buğday (Triticum aestium L.) Genotiplerinin Kuru ve Sulu Koşullardaki Verim ve Kalite Özelliklerinin Karşılaştırılması. Türkiye 10. Tarla Bitkileri Kongresi, 11-13 Eylül, 670-676, Konya. 